\title{
Internet and the Democratization of Media Content in Croatia: Content Analysis of Web Portals
}

\author{
Assistant Professor, Zorana Šuljug Vučica, PhD. \\ Department of Sociology, Faculty of Humanities and Social Sciences, University in Split, Croatia \\ zorana@ffst.hr \\ Assistant Professor, Marija Lončar, PhD. \\ Department of Sociology, Faculty of Humanities and Social Sciences, University in Split, Croatia \\ marija.loncar@ffst.hr \\ Anton Plepel, B. A. of Sociology \\ Department of Sociology, Faculty of Humanities and Social Sciences, University in Split, Croatia \\ antple@ffst.hr
}

Doi:10.5901/mjss.2015.v6n2s5p243

\section{Abstract}

Consideration of the media as communication frame from a sociological perspective points to a complex area that affects the comprehension and understanding of the media in the context of contemporary social changes. Interactive media such as Internet offer a variety of information from a number of diverse sources, and provide opportunities for social and political debates at local, national and global level. At the same time, the variety of possible forms of communication points to the pluralism of the media space and contribute to a faster flow of information. In other words, the researching of the media is operationalized inside the process of transformation and democratization of media space and content. Web portals are becoming specific areas for discussing various social issues and problems. Therefore, they are significant sources of relevant information affecting the reconceptualization of media content and changes in communication. The aim of the research was to identify aspects of the transformation of the Internet space in the process of democratization of the media in Croatia on the example of the Referendum on the constitutional definition of marriage. The authors have analysed the articles on the most visited portals in the period from November to December 2013, which reported on the subject of the Referendum on the constitutional definition of marriage, Croatia the Referendum. The analysis showed differences in the number of published articles and in content among portals, as well as a significant representation of liberal attitudes.

Keywords: a sociological perspective, content analysis, online portals, democratization of the media,

\section{Introduction: From Democratization of Media to Transformation of the Space of Dialogue}

Modern society is inconceivable without the media. They are an integral part of the lives of every individual, and they cannot be treated apart from human actions (Bandalović in Leburić et al. , 2010, 51). Nowadays media imply the culture of dialogue and the right to different opinions, argumentation in the discussion and decision-making. On the other hand, the media content is becoming a complex blend of discourses, ideologies and meanings produced by the dynamic interaction of media texts and media audiences. Therefore, the media content of various types and forms are in the centre of interests of various social debates, as well as social and sociological researches. The primary role of the media is the transmission of information and presentation of news channels in the social and political space, while the media freedom is one of the main characteristics of a democratic government. Thus, we can say that the basic democratic function of the media is to inform citizens (Čerkez, 2009, 30). In addition to dissemination of information and political education of the public, media freedom is also in the function of enabling the political activities of citizens, which is essential for the realization of their civil liberties (Peruško-Čulek, 1999, 56).

With the development of modern technology and the advent of computers, there has been relevant reconceptualization of social and cultural communication. Accordingly, we witness many changes such as increased number of possible forms of communication, media contents that are democratized and individualized, increased flow rate of information from the source to the receiver, but also the speed of obsolescence of information. But, at the same 
time the trust in the media as a reliable source of information is lost (Zgrabljic Rotar, 2005, 19). The public was once perceived as an essential foundation for democracy, as the public forum, which formed the critical debate on public issues by educated and informed individuals who were in constant interaction. Today, however, the modern media is a new type of "public", which is mostly a political, commercialized and excluded from public judgments (Splichal according to Peruško, 2011, 30).

Media society has also developed along with the development of a democratic society. It was created primarily by expanding those media that have contributed to the faster flow of information influencing in that way the whole society. The media represent the most influential agents in the formation of general interest, value judgments and political orientations of citizens. Nevertheless, the media, the public, and of course, the politics in democratic societies are in a continuous process of change (Čerkez, 2009, 28). On the one hand, the media took part in the formation of democracy and modern society. At the present time their increasingly important role is often viewed in the light of postmodern social transformation. Wasko and Splichal claim that the democratic character of communication is always two fold. Thus, democratization of communication is impossible without democratization of society as a whole. We highlight three main ideas that are inseparable from the role of communication media in modern democracy: individual freedom, human rights, the public and civil society (Wasko and Splichal according to Peruško-Čulek, 1999, 28).

Media can be defined in various ways. However, in sociological terms, the media is perceived as institutional and organizational framework of communication, and thus the concept of media is equated with the concept of discourse (Biti according to Zgrabljić Rotar, 2005, 15). It is interesting that every new media takes over the existing application forms and genres. Thus, the characteristics of contemporary media are mixing and recombination of genres and transmediality of media content. Therefore, the term "communication media" is more used than the term "mass media". This is due to the convergence of the traditional mass media around computer technology and the development of interactive media such as Internet. Internet does not meet the criteria of the mass media, because "its organizational structure does not include institutionalized production and distribution of products, commodification and audience dislocated in time and/or space and which cannot participate in the communication process" (Peruško, 2011, 36).

The democratization of media is the product of democratization of social institutions, and depends on the strength of the public sphere and civil society (Zgrabljić, 2003, 60). Internet offers and shapes "spaces of dialogue", where the participants realize their need for discussing the content and themes of common interest. Among other things, the Internet also has a wider range of technological capabilities for discussion of public issues (Oblak, 2002, 68). According to Splichal various media are predisposed to construct, shape and preserve the public sphere. The reason for this is the fact that they represent sites where different ideas and interests confront freely. It is evident that there exist differences between modern and postmodern public sphere no longer made by networks of participatory communication channels, but based upon representations in the media (Splichal according to Oblak, 2002, 63).

There is no standard definition of forms and purposes of the public sphere. The public sphere should ensure new and relevant information on a variety of issues for the citizens contributing to the future development of citizenship and democratic participation. In this context, the Internet provides an opportunity to discuss the relevant political and social problems among geographically separated individuals. In principle, occupation, education and social status are losing importance, and the exchange of arguments comes to the fore (Jensen, 2003, 350-351). However, through the loss of social status, resulting anonymity in discussion can lead to irresponsibility, speech of hate and disappearance of culture in the debate. Often, it is argued that the government should be included in creation of the public spaces (Jensen, 2003, 358).

Thornton believes that tendency toward fragmented identities appears on Internet, and that a certain shift from the "citizens" to "consumers" is noticeable. Nevertheless, the author argues that the Internet provides opportunities for revitalization of the public sphere (Thornton according to Boeder, 2005) ${ }^{1}$. New communication technologies are used in a way to deepen the practices of democratic communication. Networks are becoming structurally decentralized while the public accesses them in the ways that lead to an increase in the rate and density of the public exchange (Boeder, 2005)2. It is important to point out that the new public space is not a synonym for a new public sphere. As a public space, on the Internet it is possible to achieve discussion and democratic expressing of ideas and opinions. Accordingly, the virtual space reinforces the debate, and the virtual sphere enhances democracy (Papacharissi, 2002, 11). Internet can "empower" the public sphere, but does it in a way that is incomparable with the previous discourse of the public. In a future perspective, the Internet may not become a new public sphere, but something radically different that would improve democracy and dialogue (Papacharissi, 2002, 18) about current social and political issues such as the Referendum on

1http://firstmonday.org/ojs/index.php/fm/article/view/1280/1200. ${ }^{2}$ http://firstmonday.org/ojs/index.php/fm/article/view/1280/1200. 
the constitutional definition of marriage ${ }^{3}$.

\section{Methodological and Empirical Aspects of Research}

Daily informative web portals through various interactive features of the Internet, more and more encourage citizens to participate in the production of news, and are becoming popular places for the discussion on the various social issues. Thus, the subject of the study is the transformation of the Internet space in the context of democratization of the media on the example of the Referendum on the constitutional definition of marriage in Croatia. In other words, portals as part of the Internet space become daily sources of relevant information in the contemporary society, which affect the reconceptualization of media content. It is possible to spot the similarities/differences among portals through observing the ways the media contents are reported. Furthermore, their analysis allows examination of possible transformation induced by social changes such as the democratization of the media.

The aim of the research was to examine the extent to which daily informative portals reported on the topic by applying qualitative and quantitative content analysis, and to determine the differences in their content with regard to the subjects of the Referendum. The research also included the analysis of value orientations of the authors of the analysed texts towards the content of the Referendum during reporting, as well as the distribution of the characteristics typical of conservative and liberal views, which prevailed among portals in reporting on the research topic. In the process of designing and preparing the research, it was assumed that the analysed portals contained an equal number of published articles on the topic; that there were differences between portals in representation of terms and concepts, i. e. characteristics that were typical for liberal or conservative views; and finally that the authors took neutral value orientation when reporting on the Referendum.

Qualitative and quantitative content analyses were applied in the research. The research sample included five most visited portals according to the research of visits to websites conducted by the online research agency gemiusAudience ${ }^{4}$. The sample was defined thematically and included the articles published on selected portals in the period from 01. 11. 2013. to 01. 12. 2013. The unit of analysis was published text on portals on the subject of the Referendum. ${ }^{5}$

\section{Analysis and Results}

Content analysis included analysis of the general appearance of texts, text contents or subtopics of Referendum, value orientations of the authors towards the pre-defined contents, and aspects of the conservative and liberal attitudes with regard to the topics of Referendum. Its application enabled the (re)construction of categories throughout the analysis. Category "general appearance of texts" included analysis of the text equipment i. e. various characteristics such as the size and type of text, the structure of title, the number of photos and subcategory "other" which included the possible appearance of videos or comments. Furthermore, the value orientation is determined by the general approach to the subject, which stems from the authors' attitudes or editorial policy. ${ }^{6}$

Content analysis of selected texts was related to the analysis of topics of Referendum. At the methodological level, the stated sub-categories (or topics) were grouped into two methodological levels: individual-collective and social. Thus, for example, individual and group levels included topics such as "marriage as a life union of a woman and a man",

${ }^{3}$ Croatian Parliament in November 2013, brought the decision to call a national referendum, which was held on the 1st December 2013, based on the demands of civic initiatives In the name of the family to enter the definition of marriage as a union between a woman and a man in the Croatian Constitution. Based on the results of the Referendum, the State Election Commission of the Republic of Croatia decided to enter a provision by which the marriage is a union between a woman and a man in the Croatian Constitution (see: http://www.usud.hr/uploads/Odluka\%20u\%20povodu\%20okon\%C4\%8Danja\%20postupka\%20nadzora\%20nad\%20ustavno\%C5\%A1\%C 4\%87u\%20i\%20zakonito\%C5\%A1\%C4\%87u\%20provo\%C4\%91enja\%20dr\%C5\%BEavnog\%20referenduma\%20odr\%C5\%BEanog\%20 1.12.2013.pdf).

${ }^{4}$ http://www. audience.com.hr/.

5The sample included five most visited portals in Croatia: 24sata.hr, Jutarnji.hr, Index.hr, Tportal.hr, Večernji.hr. All articles on these portals dealing with the Referendum were analysed. There were 168 analysed articles.

${ }^{6}$ According to the following typology of value orientations of the author retrieved from Sušnjić (1973, 253): positive (+) means any assessment that is affirmative in relation to the subject in question; negative (-) means any negative or critical assessment in relation to the subject matter described in the content; neutral (0) means any general or specific statement of something just described or claimed, but without taking a certain attitude; programmatic (!) means any assessment which proposes something that "should be" in relation to the matter in question. 
"marriage is the foundation of the family", "family stability" etc. On the other hand, social methodological level included topics such as "legal protection of children, marriage and family", "the existing Family Law", "the family is the foundation of society", etc. (see Table 1). Concerning Referendum topics, reading texts and viewing web pages ${ }^{7}$ related to the subject of the Referendum enabled the construction of a temporary categorization prior to analysis. However, the categorical apparatus was reconstructed during the analysis.

Table 1. Topics of referendum due to the methodological level

\begin{tabular}{|l|l|}
\hline Methodological Level & \multicolumn{1}{c|}{ Topics of Referendum } \\
\hline individual-collective & $\begin{array}{l}\text { C1 (marriage as a life union between a woman and a man), C2 (marriage is the foundation of the } \\
\text { family), C3 (family stability), C4 (reproduction depend on man and woman), C5 (family structure is } \\
\text { important for a child) }\end{array}$ \\
\hline social & $\begin{array}{l}\text { C6 (the legal protection of children, marriage and family), C7 (existing Family Law), C8 (marriage as a } \\
\text { generally accepted social norm), C9 (part of the culture and identity of the Croatian people), C10 (family } \\
\text { is the foundation of society) C11 (equalization of same-sex partnerships and marriage), 12 (adoption of } \\
\text { children by same-sex couples), C13 (protection of children born out of wedlock), C14 (other) }\end{array}$ \\
\hline
\end{tabular}

Furthermore, we also conducted an analysis of concepts and terms (i. e. characteristics) that are typical for the conservative or liberal attitudes on a general level. Categories of conservative and liberal attitudes have been taken partly from web pages dealing with conservative and liberal beliefs for the purposes of constructing a categorical apparatus during the analysis. ${ }^{8}$ It is important to emphasize that sub-categories imply general features of liberalism and conservatism, in the context of different world-view orientation. For example, attitudes such as "belief in government actions to achieve equality of opportunity and equality for all", "marriage is a union of people who love each other" and "forbidding same-sex marriages threaten the civil rights" were categorized as characteristics of liberal attitudes on the studied subject. On the other hand, terms such as "belief in personal responsibility, limits of government, free market", "high value of existing institutions as constructs of customs and tradition", "traditional values and the defence of national identity" and the like, were related to the characteristics of conservative attitudes (see Table 2).

Table 2. Characteristics of liberal and conservative attitudes

\begin{tabular}{|l|l|l|}
\cline { 2 - 4 } \multicolumn{1}{c|}{ Attitude } & \multicolumn{1}{c|}{ Characteristics } \\
\hline liberal & $\begin{array}{l}\text { L1 (the belief in government actions to achieve equality of opportunity and equality for all), L2 (duty of the } \\
\text { government to protect the civil rights of the individual and human rights), L3 (natural rights belong to all } \\
\text { people), L4 (majority rights are tempered by minority rights), L5 (support to the changes in society), L6 } \\
\text { (marriage is a union of people who love each other), L7 (all individuals, regardless of their sexual } \\
\text { orientation, have the right to marry), L8 (prohibiting same-sex marriages threaten the civil rights), L9 other } \\
\text { (separation of church and state, the issue of abortion as a personal choice, equal rights and freedoms) }\end{array}$ \\
\cline { 2 - 3 } & conservative & $\begin{array}{l}\text { K1 (belief in personal responsibility, government limits, free markets), K2 (traditional values and the defence } \\
\text { of national identity), K3 (high value of existing institutions as constructs of customs and tradition), K4 (faith } \\
\text { in super natural forces that are guiding human affairs), K5 (acceptance of human inequality and the } \\
\text { expected consequences of the social hierarchy), K6 (recognition of the need for a sense of community } \\
\text { among individuals who will emotionally connect with society), K7 (marriage is the union of one man and one } \\
\text { woman), K8 (same-sex unions violate moral and religious beliefs that marriage is a union of one man and } \\
\text { one woman), K9 other (government should not restrict faith and religious freedom, abortion as murder of a } \\
\text { human being, endangering the traditional family) }\end{array}$ \\
\hline
\end{tabular}

Analysis showed that 24sata. $h r$ is the portal with the most published articles on the subject of Referendum, while Večernji. $h r$ is the portal with a minimum of published articles. In other words, 24sata. $h r$ has the largest distribution of referendum topics, and Večernji. $h r$ the least. Almost half of the texts in on all the portals deal with the topic of marriage as a life union between a woman and a man. Less than $2 \%$ of the texts (except texts on Večernji. $h r$ ) deal with topics such as reproduction, protection and adoption of children, culture and identity, and marriage as the foundation of the family. On the other hand Večernji. $h r$ is much more focused on the above stated topics because the authors of the

\footnotetext{
${ }^{7}$ http://uimeobitelji.net/.

${ }^{8}$ According to the data retrieved from http://www.studentnewsdaily.com/conservative-vs-liberal-beliefs and http://academic.regis.edu/ jriley/libcons.htm 
articles were writing not only about the marriage as a union between a man and woman, but also about the aspects of education of children, the family as the foundation of society and other social factors that are associated with marriage.

Most common (about $20 \%$ of texts on all portals) characteristics of the analysed liberal attitudes are following: "banning same-sex marriages threaten the civil rights"; "belief in government actions to achieve equality of opportunity and equality for all", "the duty of government to protect the civil rights the individual and human rights", "the rights of the majority are tempered by minority rights". It is noticeable that a special emphasis is on the duties of the government, as well as on the protection of existing rights in the context of civil rights. Among the conservative attitudes, the most used characteristics are those that stress tradition, religion and national identity, for example, "protection of traditional values and the defence of national identity" and "belief in supernatural forces that are guiding human affairs". The analysis of attitudes and their characteristics shows that the distribution of liberal attitudes is higher than the distribution of conservative attitudes in texts on all portals, except on Večernji. $h r$, where the situation is reversed (see Table 3). 24sata. $h r$ is a portal with the most liberal characteristics.

Table 3. The analysed texts on portals with regard to the liberal and conservative attitudes

\begin{tabular}{|c|c|c|c|c|c|c|}
\hline \multirow{2}{*}{ Internet Portal } & \multicolumn{2}{|c|}{ Number of Published Articles } & \multicolumn{4}{|c|}{ Attitudes } \\
\cline { 3 - 6 } & $f$ & $\%$ & \multicolumn{3}{|c|}{ Liberal } & \multicolumn{2}{c|}{ Conservative } \\
\cline { 2 - 6 } & 49 & 29,2 & 51 & 31,0 & 30 & 22,9 \\
\hline 24sata. $h r$ & 40 & 24,0 & 35 & 21,2 & 34 & 25,9 \\
\hline Jutarnj. $h r$ & 38 & 22,6 & 42 & 24,4 & 37 & 28,2 \\
\hline Index. $h r$ & 27 & 16,0 & 31 & 18,7 & 15 & 11,4 \\
\hline Tportal. $h r$ & 14 & 8,3 & 6 & 3,6 & 15 & 11,4 \\
\hline Večernji. $h r$ & 168 & 100,0 & 165 & 100,0 & 131 & 100,0 \\
\hline$\Sigma$ & & & &
\end{tabular}

The results of analysis have revealed that the most prevalent are the negative value orientations of the author, or the negative or critical attitudes of the authors toward the topics of Referendum. In other words, the authors have quite negatively referred to the aspects involving the definition of marriage as the union of a man and a woman, which was the main topic of Referendum. On the other hand, Večernji. hr is the only portal dominated by higher incidence of positive value orientations of the author. The evaluations of the authors are affirmative in relation to the conservative attitudes on the subject of the Referendum. Thereby the fact that Referendum provides legal protection of the children, marriage and family stability is assessed especially positive.

As for the neutral value orientations of the author, Jutarnji. hr and Index. hr have the same number of published articles in which we observe a neutral value orientation of authors toward the topics of Referendum. At the same time the analysis shows that programmatic value orientation of the authors which suggests something that "should be" in relation to the subject matter is the least represented in texts. Specifically, the authors occupy a programmatic orientation toward the voting of citizens in the upcoming referendum. They suggest them to vote but without explicitly saying for or against. Thus, Index. hr is a portal with the most programmatic orientation of the authors.

Finally, the analysis showed that portals differ in the number of published articles and value orientations of the author. Furthermore, the analysed portals are slightly different with regard to the distribution characteristics typical of liberal or conservative attitudes. However, analysis of the general appearance of the texts also showed similarities between them according to the size and type of texts, number of images and the use of multimedia. The analysed texts consist mostly of five or more paragraphs, and most of them are in form of a report. More than $75 \%$ of articles per portals have one or two images associated with text, and a negligible number of analysed articles that have video as a supplement. Portals differ significantly with respect to the number of comments on the article. Index. hr stands out with more than half of the articles that have up to 200 comments while the texts on Tportal. hr have no comments. Considering the above stated, it is possible to conclude that the analysed portals use less internet technological capabilities such as multi-media and connectivity facilities, as was shown by some other analysis of daily news portals in Croatia (such as Benković and Balabanić, 2010).

\section{Conclusion}

By considering the media as a framework for communication in the context of a sociological perspective, we are entering a complex area, which undoubtedly has an impact on everyday life. Defining the media in different ways as well as 
ambivalent opinions about new media and communication technologies point out the complexity of media meaning. It is also important to consider the wider context of social and political processes, and place the questioning of media topics in the processes of transformation and democratization of media space, and media content. On the other hand, the process of democratization of the media obviously leads to some necessary changes in social communication.

The emergence of the Internet as a new media and online sphere as a "new" communication space, undoubtedly results with a large number of sources of information, as well as with stated changes in social and political communication. A larger number of web portals and pluralism of media content, more accurately, various topics and styles, create space for a dialogue on the Internet through its transformation. Accordingly, we can speak of pluralism of the media space and understanding of mediated communication space in a different way, while the changes and processes in contemporary society and culture can be conceptualized in the context of the transformation and democratization of the media.

In other words, the reconceptualization of social and cultural communication is enabled through more present and influential factor in the lives of individuals and social groups - through the Internet. The Internet with its interactive dimensions and capabilities for discussion and dialog can serve as a mean for revitalization of the public sphere. Discussions in this regard are going towards the transformation of the space of dialogue where online sphere as a communication space becomes of central importance. Finally, we can conclude that the pluralism of the media space occurs through the development of new media and the process of democratization of the media. In such social atmosphere, the online portals with their specific way of reporting on different issues provide the relevant information and in perspective can reinforce dialogue among interested individuals. Such changes in the area of media become the central interest of contemporary social debates and sociological research and analysis.

\section{References}

Benković, V. \& Balabanić, I. (2010). Analiza sadržaja najposjećenijih internetskih portala. Medijska istraživanja, 16 (2), 43-56. [Online] Available: http: //hrcak. srce. hr/index. php?show=clanak\&id_clanak_jezik=95909 (February 18, 2014)

Boeder, P. (2005). Habermas' heritage: The future of the public sphere in the network society. First Monday, 10 (9). [Online] Available: http: //firstmonday. org/ojs/index. php/fm/article/view/1280/1200 (February 18, 2014)

Čerkez, I. (2009) Osnovna obilježja medijske komunikacije u demokratskoj kulturi. Socijalna ekologija: časopis za ekološku misao i sociologijska istraživanja, 18 (1), 28-45. [Online] Available: http://hrcak. srce.hr/index.php?show=clanak\&id_clanak_jezik=64293 (February 18, 2014)

Jensen, J. L. (2003). Public Spheres on the Internet: Anarchic or Government-Sponsored - A Comparison. Scandinavian Political Studies, 26 (4), 349-374. [Online] Available: www.researchgate.net/publication/227715533_Public_Spheres_on_the_Internet_ Anarchic_or_GovernmentSponsored_A_Comparison (February 18, 2014)

Leburić, A. , Maroević, M. , \& Šuljug, Z. (2005). Legalna ilegala: Sociološko istraživanje neplanske izgradnje u Splitu. Split: Naklada Bošković.

Leburić, A. , Lončar, M. , Šuljug Vučica, Z. , \& Bandalović, G. (2010). Jezična stvarnost medija. Split: Redak.

Oblak, T. (2002). Internet kao medij i normalizacija kibernetskog prostora. Medijska istraživanja, 8 (1), 61-76. [Online] Available: http: I/hrcak. srce. hr/index. php?show=clanak\&id_clanak_jezik=36810 (February 18, 2014)

Papacharissi, Z. (2002). The virtual sphere: the internet as a public sphere. New Media \&Society, 4 (1), 9-27. [Online] Available: http: I/tigger. uic. edu/ zizi/Site/Research_files/VirtualSphere. pdf (February 18, 2014)

Peruško, Z. (2011). Što su mediji?, In Z. Peruško (Eds. ), Uvod u medije (pp. 15-40). Zagreb: Jesenski i Turk.

Peruško-Čulek, Z. (1999). Demokracija i mediji. Zagreb: Barbat.

Zgrabljić, N. (2003). Hrvatska medijska politika i javni mediji. Medijska istraživanja, 9 (1), 59-75. [Online] Available: http: //hrcak. srce. hr/index. php?show=clanak\&id_clanak_jezik=36753 (February 18, 2014)

Zgrabljić Rotar, N. (2005). Mediji - medijska pismenost, medijski sadržaji i medijski utjecaji. In N. Zgrabljić Rotar, N. (Ed. ) Medijska pismenost i društvo (pp. 9-44). Sarajevo: Mediacentar.

\section{Internet sources}

http: //www. audience. com. hr/ (February 10, 2014)

http: //www. studentnewsdaily. com/conservative-vs-liberal-beliefs/ (April 14, 2014)

http: //academic. regis. edu/jriley/libcons. htm (April 14, 2014)

http: //uimeobitelji. net/ (April 14, 2014)

http://www.usud.hr/uploads/Odluka\%20u\%20povodu\%20okon\%C4\%8Danja\%20postupka\%20nadzora\%20nad\%20ustavno\%C5\% A1\% C4\%87u\%20i\%20zakonito\%C5\%A1\%C4\%87u\%20provo\%C4\%91enja\%20dr\%C5\%BEavnog\%20referenduma\%20odr\%C5\%BE anog\%201. 12. 2013. pdf (March 9, 2015) 